\title{
INFLUENCE OF STAGE OF CYCLE, PROGESTAGEN TREATMENT AND DOSE OF OESTROGEN ON UTERINE MOTILITY IN THE EWE
}

\author{
K. P. CROKER AND J. N. SHELTON* \\ Department of Animal Husbandry, University of Sydney, \\ Sydney, N.S.W. 2006, Australia
}

(Received 17th August 1972)

Low fertility in ewes after control of oestrus with progestagens has been attributed to abnormal transport and/or reduced viability of spermatozoa in the female tract (Quinlivan \& Robinson, 1967, 1969). Smith \& Allison (1971) have shown an effect of progestagen treatment on the quantity of cervical mucus produced at the subsequent oestrus and have suggested that this prevents the establishment of a normal population of spermatozoa in the cervix. Another factor contributing to transport of spermatozoa is uterine motility (Mattner, 1963; Mattner \& Braden, 1963; Lightfoot \& Restall, 1971).

Differences in uterine motility at oestrus and mid-cycle have been reported by Polovceva (1940) and Mann (1969) and they suggested that uterine motility was affected by ovarian hormones. It is therefore likely that manipulation of the oestrous cycle by use of progestagens and the associated abnormalities in steroid secretion (Smith \& Robinson, 1969, 1970) might result in aberrant patterns of uterine motility that adversely affect transport of spermatozoa.

The experiments described here were designed to study uterine motility at different stages of the oestrous cycle, the effect of progestagen treatment, and the effect of dose of oestrogen.

Mature entire Merino ewes were used in Exps 1 and 2; spayed ewes were used in Exp. 3. Vasectomized rams fitted with Sire-sine harnesses and crayons (Radford, Watson \& Wood, 1960) were used for detection of oestrus.

For observation of uterine motility, anaesthesia was induced with Pentothal (Abbott Laboratories) and maintained with cyclopropane. Cyclopropane was used to minimize the effect of anaesthesia on uterine motility (see Friedman, 1965). Following laparotomy, the cranial two-thirds of the uterus were exposed with a minimum of tension and a 10-min period allowed for activity to stabilize. This was followed by a 10-min period of observation during which the same observer noted the direction in which each uterine contraction was propagated. In the entire ewes, the contractions of the uterine horn on the side of the active ovary (Smith \& Robinson, 1970) were observed whereas in the ovariectomized ewes, the activity of the right uterine horn was observed. Individual contractions were classified as moving towards the body of the uterus, moving towards the Fallopian tube, stationary, or indefinite. The

\footnotetext{
* Present address: Cobbitty Road, Cobbitty, N.S.W. 2570, Australia.
} 
frequencies of total contractions for each ewe were compared between treatments by standard analysis of variance while the number of contractions in each classification were compared between treatments by $\chi^{2}$ analysis.

Experiment 1. Vasectomized rams were 'joined' with twenty-seven ewes which subsequently were observed every $6 \mathrm{hr}$. Ewes were allocated to treatment groups when first detected to be in oestrus. It was assumed that they had been in oestrus for 0 to $6 \mathrm{hr}$ when first observed. Ewes in Group 1 were examined for uterine motility within the period of 2 to $8 \mathrm{hr}$ after the start of oestrus (early oestrus). Those in Group 2 were examined 39 to $45 \mathrm{hr}$ after the commencement of oestrus (early postoestrus) while the ewes in Group 3 were examined on the 10th or 11 th day after the initiation of oestrus (mid-cycle).

Table 1 shows a marked decrease in frequency of contractions from early oestrus to mid-cycle $(P<0.001)$, together with a significant change in the classification of contractions $(P<0.001)$.

Table 1. The effect of stage of oestrous cycle on uterine motility in the ewe

\begin{tabular}{|c|c|c|c|c|c|c|c|c|}
\hline \multirow[b]{2}{*}{$\begin{array}{l}\text { Stage of } \\
\text { cycle }\end{array}$} & \multirow[b]{2}{*}{$\begin{array}{l}\text { No. of } \\
\text { ewes }\end{array}$} & \multirow[b]{2}{*}{$\begin{array}{l}\text { Total no. of } \\
\text { contractions }\end{array}$} & \multirow[b]{2}{*}{$\begin{array}{l}\text { Average } \\
\text { no./min }\end{array}$} & \multicolumn{4}{|c|}{ Percentage of contractions } & \multirow[b]{2}{*}{$P$} \\
\hline & & & & $\begin{array}{c}\text { Towards } \\
\text { tubes }\end{array}$ & $\begin{array}{c}\text { Towards } \\
\text { body }\end{array}$ & Stationary & Indefinite & \\
\hline $\begin{array}{l}\text { Early } \\
\text { oestrus } \\
\text { Post- }\end{array}$ & 9 & 287 & 3.2 & $44 \cdot 6$ & $35 \cdot 5$ & $11 \cdot 1$ & 8.7 & \\
\hline $\begin{array}{c}\text { oestrus } \\
\text { Mid-cycle }\end{array}$ & $\begin{array}{l}9 \\
9\end{array}$ & $\begin{array}{l}209 \\
140\end{array}$ & $\begin{array}{l}2 \cdot 3 \\
1 \cdot 6\end{array}$ & $\begin{array}{l}16 \cdot 7 \\
16 \cdot 4\end{array}$ & $\begin{array}{l}69 \cdot 9 \\
47 \cdot 9\end{array}$ & $\begin{array}{l}11 \cdot 0 \\
30 \cdot 0\end{array}$ & $\begin{array}{l}2 \cdot 4 \\
5 \cdot 7\end{array}$ & $<0.001$ \\
\hline$P$ & & & $<0.001$ & & & & & \\
\hline
\end{tabular}

Experiment 2. Intravaginal sponges impregnated with $30 \mathrm{mg}$ Cronolone (Searle) were inserted in nine ewes on the 11th day of the cycle in order to synchronize oestrus. They were inserted at mid-cycle to ensure that the oestrus following their withdrawal after 12 days was not related to a normal cyclic oestrus. Eight ewes were not synchronized and served as controls. The ewes were checked for oestrus every $6 \mathrm{hr}$ and were examined for uterine motility within the period of 8 to $28 \mathrm{hr}$ after the start of oestrus.

Table 2 shows no difference between normal and synchronized ewes in the frequency of contractions despite a significant difference in the distribution of the various classifications $(P<0 \cdot 01)$. The patterns of contractions observed in both groups were very different from those observed in the oestrous ewes in Exp. 1 and tended to resemble the activity observed after oestrus and at mid-cycle. The ewes were examined later after the onset of oestrus than those in Exp. 1 ( 8 to $28 \mathrm{hr}$ as compared to 2 to $8 \mathrm{hr}$ ) which may account for the difference.

Experiment 3. Twenty-nine ovariectomized ewes were brought into oestrus by priming with $10 \mathrm{mg}$ progesterone daily for 12 days, followed by a single injection of 10,30 or $90 \mu \mathrm{g}$ oestradiol benzoate (ODB) $60 \mathrm{hr}$ after the last injection of progesterone (Robinson \& Moore, 1956). All ewes were examined for uterine motility approximately $36 \mathrm{hr}$ after the injection of ODB. 
Table 3 suggests an association between increasing doses of ODB and increasing frequency of contractions but this was not significant. There was a significant effect of dose on the distribution of the various classifications of contractions $(P<0.001)$. A high proportion of the contractions observed following the highest dose were not classified because of their small amplitude and rapid dissipation.

In general, the observations made in these three experiments are in agreement with those of Mann (1969) but differ from those of Polovceva (1940), who claimed that the uterus is quiescent at mid-cycle. An interesting feature of Exp. 1 is the apparent rapid reduction in motility after the end of oestrus.

Table 2. The effect of progestagen on subsequent uterine motility in the ewe

\begin{tabular}{|c|c|c|c|c|c|c|c|c|}
\hline \multirow[b]{2}{*}{ Treatment } & \multirow[b]{2}{*}{$\begin{array}{l}\text { No. of } \\
\text { ewes }\end{array}$} & \multirow[b]{2}{*}{$\begin{array}{l}\text { Total no. of } \\
\text { contractions }\end{array}$} & \multirow[b]{2}{*}{$\begin{array}{l}\text { Average } \\
\text { no. } / \text { min }\end{array}$} & \multicolumn{4}{|c|}{ Percentage of contractions } & \multirow[b]{2}{*}{$\mathbf{P}$} \\
\hline & & & & $\begin{array}{c}\text { Towards } \\
\text { tubes }\end{array}$ & $\begin{array}{l}\text { Towards } \\
\text { body }\end{array}$ & Stationary & Indefinite & \\
\hline \multirow{2}{*}{$\begin{array}{l}\text { Normal } \\
\text { Syn- } \\
\text { chronized }\end{array}$} & 8 & 171 & $2 \cdot 1$ & $13 \cdot 5$ & $49 \cdot 7$ & $32 \cdot 2$ & $4 \cdot 7$ & \multirow{2}{*}{$<0.01$} \\
\hline & 9 & 193 & $2 \cdot 1$ & $10 \cdot 4$ & $68 \cdot 9$ & $18 \cdot 7$ & $2 \cdot 1$ & \\
\hline$P$ & & & N.S. & & & & & \\
\hline
\end{tabular}

Table 3. The effect of oestrogen on uterine motility in the spayed ewe

\begin{tabular}{|c|c|c|c|c|c|c|c|c|}
\hline \multirow{2}{*}{$\begin{array}{c}\text { Dose of } \\
O D B \\
(\mu g)\end{array}$} & \multirow[b]{2}{*}{$\begin{array}{l}\text { No. of } \\
\text { ewes }\end{array}$} & \multirow[b]{2}{*}{$\begin{array}{l}\text { Total no. of } \\
\text { contractions }\end{array}$} & \multirow[b]{2}{*}{$\begin{array}{l}\text { Average } \\
\text { no./min }\end{array}$} & \multicolumn{4}{|c|}{ Percentage of contractions } & \multirow[b]{2}{*}{$\mathbf{P}$} \\
\hline & & & & $\begin{array}{c}\text { Towards } \\
\text { tubes }\end{array}$ & $\begin{array}{c}\text { Towards } \\
\text { body }\end{array}$ & Stationary & Indefinite & \\
\hline $\begin{array}{l}10 \\
30 \\
90\end{array}$ & $\begin{array}{r}9 \\
10 \\
10\end{array}$ & $\begin{array}{l}244 \\
282 \\
350\end{array}$ & $\begin{array}{l}2 \cdot 7 \\
2 \cdot 8 \\
3 \cdot 5\end{array}$ & $\begin{array}{r}5 \cdot 7 \\
38 \cdot 7 \\
33 \cdot 1\end{array}$ & $\begin{array}{l}73 \cdot 4 \\
24 \cdot 8 \\
11 \cdot 4\end{array}$ & $\begin{array}{r}14.8 \\
14.2 \\
9 \cdot 4\end{array}$ & $\begin{array}{r}6 \cdot 1 \\
22 \cdot 3 \\
46 \cdot 0\end{array}$ & $<0.001$ \\
\hline$P$ & & & N.S. & & & & & \\
\hline
\end{tabular}

The need for more detailed study of the relationship between stage of oestrus and motility is indicated. Further, these observations show no difference in the frequency of uterine contractions at oestrus in progestagen-treated ewes compared to normal ewes. Differences might be apparent if observations were made earlier in oestrus. The major effect of progestagen treatment was an increased proportion of contractions moving towards the body of the uterus, contrary to the desired direction of sperm transport. This may be related to the finding of Quinlivan \& Robinson $(1967,1969)$ that progestagen treatment is associated with a reduction below normal in the numbers of spermatozoa in the Fallopian tubes at the subsequent oestrus. This effect would be analogous to the failure of sperm transport in IUD-treated ewes which Brinsfield \& Hawk (1969), Mann (1969), Hawk (1970) and Warren \& Hawk (1971) attribute to a change in direction of uterine contractions. An inadequate sperm 
reservoir in the cervix of the progestagen-treated ewe has been reported by Quinlivan \& Robinson (1969). It can be argued that the pattern of motility in treated ewes would favour expulsion rather than retention of spermatozoa in the cervix and that this adverse effect is compounded with that of abnormal cervical mucus (Smith \& Allison, 1971).

Experiment 3 shows the dependence of frequency and direction of uterine contractions on the dose of oestrogen. Smith \& Robinson (1970) have suggested a change from normal in the pattern of oestrogen secretion in progestagentreated ewes. Such a change could affect transport of spermatozoa not only by changes in cervical mucus (Smith \& Allison, 1971) but also by alteration in uterine motility.

The authors wish to acknowledge the assistance of Professor T. J. Robinson in the preparation of this manuscript and the technical assistance of Mrs C. Camidge and $\mathrm{Mr}$ J. Ellsmore. The project received financial support from the Australian Research Grants Committee. The first author was supported by a G. D. Searle \& Co. Research Studentship and now is holder of an Australian Wool Board Post-graduate Scholarship.

\section{REFERENCES}

BRINSFIELD, T. H. \& HAWK, H. W. (1969) Modification of the direction of uterine contractions by intra-uterine devices in the ewe. 7. Reprod. Fert. 18, 535.

Friedman, E. A. (1965) Effects of drugs on uterine contractility. Anesthesiology, 20, 409.

HAWK, H. W. (1970) Rapid disruption of sperm transport mechanisms by intra-uterine devices in the ewe. F. Reprod. Fert. 23, 139.

Lightroot, R. J. \& Restall, B. J. (1971) Effects of site of insemination, sperm motility and genital tract contractions on transport of spermatozoa in the ewe. F. Reprod. Fert. 26, 1.

MANN, L. I. (1969) Effect of the IUCD on uterine motility in the ewe. Fert. Steril. 20, 951.

Matrner, P. E. (1963) Spermatozoa in the genital tract of the ewe. III. The role of spermatozoan motility and of uterine contractions in transport of spermatozoa. Aust. F. biol. Sci. 16, 877.

MAtTNer, P. E. \& Braden, A. W. H. (1963) Spermatozoa in the genital tract of the ewe. I. Rapidity of transport. Aust. F. biol. Sci. 16, 473 .

Polovceva, V. V. (1940) The rhythmic movements of the ewe at different periods of the sexual cycle. Vest. sel'.-khoz. Nauki, Mosk. 1, 127.

Quinuivan, T. D. \& Robinson, T. J. (1967) The number of spermatozoa in the Fallopian tubes of ewes at intervals after artificial insemination following withdrawal of SC-9880 impregnated intravaginal sponges. In: The Control of the Ovarian Gycle in the Sheep, p. 177. Ed. T. J. Robinson. Sydney University Press, Sydney.

Quinlivan, T. D. \& Robinson, T. J. (1969) Numbers of spermatozoa in the genital tract after artificial insemination of progestagen-treated ewes. F. Reprod. Fert. 19, 73.

RAdford, H. M., Watson, R. H. \& Wood, G. F. (1960) A crayon and associated harness for the detection of mating under field conditions. Aust. vet. F. 36, 57.

Robinson, T. J. \& MoorE, N. W. (1956) The interaction of oestrogen and progesterone on the vaginal cycle of the ewe. F. Endocr. 14, 97.

Smrth, J. F. \& Allison, A. J. (1971) The effect of exogenous progestagen on the production of cervical mucus in the ewe. 7 . Reprod. Fert. 24, 279.

Smrtr, J. F. \& Robinson, T. J. (1969) Luteal function in the Merino ewe and the effect of exogenous progestagen. 7. Endocr. 44, 79.

Smith, J. F. \& Robinson, T. J. (1970) The effect of exogenous progestagen on the levels of free oestrogen in the ovarian vein plasma of the ewe. 7 . Endocr. 48, 485.

WARREN, J. E. \& HAWK, H. W. (1971) Effect of an intrauterine device on sperm transport and uterine motility in sheep and rabbits. F. Reprod. Fert. 26, 419. 